\title{
Combating the threat of stem cell tourism through patient education and government regulation
}

This article was published in the following Dove Press journal:

Innovation and Entrepreneurship in Health

27 January 2016

Number of times this article has been viewed

\author{
Burhan Gharaibeh ${ }^{1,2}$ \\ Jordan E Anderson ${ }^{3}$ \\ Bridget M Deasy' \\ 'CellStock, Pittsburgh, PA, USA; \\ ${ }^{2}$ Department of Natural Sciences \\ and Engineering Technology, Point \\ Park University, Pittsburgh, PA, USA; \\ ${ }^{3}$ Department of Veterans Affairs, \\ Providence Veterans Administration \\ Medical Center, Providence, RI, USA
}

Correspondence: Bridget M Deasy CellStock, 920 William Pitt, Building B4, Suite 249, Harmar, PA 15238, USA Email deasybm@gmail.com

\begin{abstract}
Advances in stem cell research and media publicity of stem cell potential have raised the hopes of patients with severe disabilities and conditions which lack a cure. While stem-cell-based therapies are the clinical standard of care for a few hematological conditions, stem cell tourism continues to rise worldwide. This rise is driven in part by patients' need for alternative treatment for difficult conditions and increased online access to health information. Unfortunately, clinics around the world are exploiting patients' hopes by offering supposed stem cell therapies, without credible scientific rationale, oversight, or patient protections. Occurring particularly in Asia and South America, treatments which are illegal in most countries are being offered for what are often considered incurable conditions. A survey of health organization websites showed that while $71 \%$ of these websites provided information about stem cell treatment/ research, only $18 \%$ of those sites included a direct warning or caution about stem cell treatments abroad. A number of professional organizations have published guidance documents to shine a light on the dangers of stem cell tourism. Comprehensive government regulations exist in the US, Europe, and several other countries, so that approvals for stem cell treatments occur only after extensive safety testing has occurred. In this review, we discuss issues related to stem cell treatments, including the patients' needs for educational resources, and we describe the process of regulatory approval for cell therapies using the US system as an example.
\end{abstract}

Keywords: transnational health care, medical tourism, regenerative medicine, cell therapies, CAM, complementary and alternative medicine

\section{Medical tourism}

Transnational medical tourism, or global travel for medical treatment, is on the rise. Increasingly, patients are crossing borders to receive health care, bringing attention to the social, political, and economic issues associated with international health care. ${ }^{1-4}$ The diversity of reasons why patients travel for treatment include: access to care unavailable in homestates, financial incentives, impacts related to health-care privatization, perceptions related to quality of care and others. ${ }^{5,6}$ A network-based study of the push and pull of medical travel shows that the role of networks is critical to understand choice of treatment, provider, and destination. Importantly, the choice of destination and provider appears to be largely the result of informal networks (web fora, personal recommendations, and support groups), although distance, costs, expertise, and availability of treatment all are factors influencing patients' decision to travel. ${ }^{5}$

Reliable data are scarce on the number of persons traveling abroad to receive health care. ${ }^{6,7}$ Estimates included in a US Centers for Disease Control report suggest that 60,000-750,000 Americans travel annually, ${ }^{8}$ while other sources suggest that upward of 
1 million Americans travel abroad to receive health care that is either unavailable or unaffordable in the US. ${ }^{9,10}$ Most commonly, cosmetic and dentistry services are sought, in addition to treatments for cardiovascular and orthopedic disorders. Cancer, reproductive, and weight loss treatments are also among the most sought after therapies. Common destinations include India, People's Republic of China, Mexico, Brazil, Malaysia, Thailand, and Singapore.

This review will focus on cell therapy tourism, in which treatments are offered using autologous or allogeneic cells to alleviate a very wide range of conditions. Advances in stem cell research over the past decade have raised media attention and consumer awareness of new medical possibilities. Naturally, this raises the hopes of patients with severe disabilities and life-threatening conditions which lack a cure. In addition to the common countries for medical tourism, growth in the stem cell market is occurring in Latin America including Cuba, Brazil, Argentina, and Costa Rica. ${ }^{11}$ Plainly, patients travel to seek stem cell treatment for conditions that have not been successfully treated in their homelands using standard care approaches. Several factors have contributed to the rise in the number of traveling patients including increased online information and clinic websites, increased media hype regarding stem cell possibilities, and increased access to health-care information. Patients seeking online health-care information are quickly exposed to stem cell clinic websites. These clinics offer attractive results which are unproven and potentially dangerous to the scientific and medical communities, and they occur in countries which have little or incomplete government regulation.

\section{Need for treatments, a market for hope}

Traveling patients often are seeking treatment for serious lifethreatening conditions to debilitating conditions. Likewise, ongoing research exists for the use of stem cells in a regenerative medicine approach for just about all medical areas ranging from heart disease to osteoarthritis to cosmetic procedures such as hair replacement. Stem cell research is focused on new approaches for unmet needs of existing therapy or improving current methods. The number of potential patients in search of options is large. For example, the World Health Organization estimates that 17.3 million people died from cardiovascular disease in 2008, and this number will rise to 23.3 million by $2030 .{ }^{12}$ Cancer-related issues led to more than 8.2 million deaths in 2012. ${ }^{13}$ In terms of needs for organ repair or replacement, in the US alone, nearly 78,000 patients are currently on the active waiting list for a life-saving organ transplant
(2015), with over 32,000 transplants from 15,670 donors in 2014, still many patients will die while on the waiting list. ${ }^{14,15}$ Worldwide, large numbers of people are affected by debilitating conditions such as osteoarthritis; 20 million people are afflicted with cartilage defects and injuries, ${ }^{16}$ and the worldwide incidence of arthrosis is 20-25 million cases. ${ }^{17}$ Standard treatments work for many, still there is a large market for patients in need of hope and additional therapies.

Stem cell clinic websites are keen to the notion that patients are seeking options and alternatives. Indeed, a recent study of stem cell clinic websites reported that the five most commonly offered stem cell treatments were for conditions which have limited options - multiple sclerosis, antiaging, Parkinson's disease, stroke, and spinal cord injury. ${ }^{18}$ Further, Connolly et al ${ }^{18}$ found that $88 \%$ of online clinics made specific claims that their treatment was effective, and $16 \%$ of the online clinics described the curative potential of their treatment. Stem cell clinic sites use what may be considered emotionally-charged words to despairing patients including "options", "alternatives", "individualized", "natural healing", several even explicitly state "cure". Most websites provide scientific information about stem cells in general, and gain (or attempt to gain) credibility by the use of scientific publications and the inclusion of scientists and physicians, particularly those from the US/Canada, Europe, or Australia.

\section{Stem cell research and clinical trials}

Despite ongoing extensive research and a high level of patient interest/willingness, few cell therapies are currently in clinical use, even within accredited settings. This is because either the technologies have not had time and/or funds to pass through the approval process or because supporting science for such treatment offered abroad does not exist. A number of professional organizations have published guidance documents for the responsible conduct of translational stem cell research in order to address concerns regarding damage to the scientific field of stem cell research due to countries which have limited oversight and allow treatment to occur in the absence of credible scientific rationale, transparency, oversight, or patient protections. ${ }^{19}$

Unfortunately, the average patient who is traveling for care may not fully understand the process for science to reach therapy. Stem-cell-based therapies are the clinical standard of care for only a few conditions, such as leukemia and, more recently, for some burns and corneal disorders, although research is heavily funded. The US National Institutes of Health (NIH) has spent billions on all stages of research 


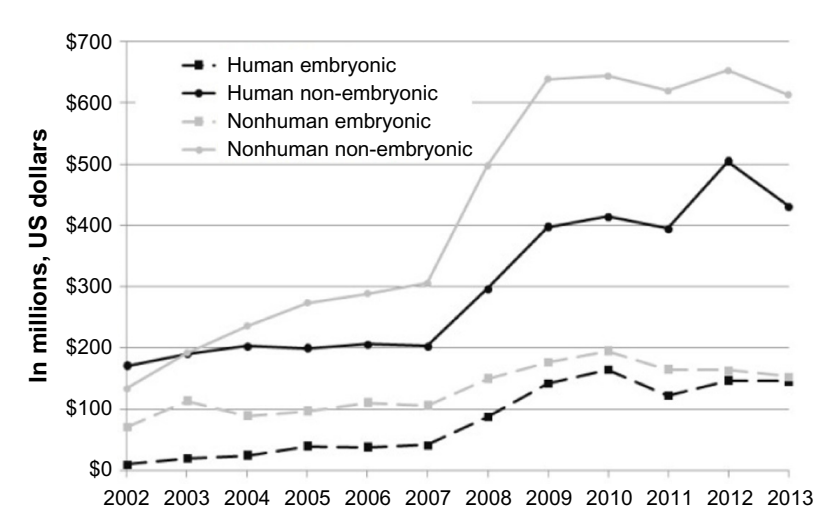

Figure I The US NIH spending on stem cell research 2002-20I3.

Note: Data from National Institutes of Health, US Department of Health and Human Services. NIH Stem Cell Research Funding, fy 2002-2013. Bethesda, MD: NIH. Available from: http://stemcells.nih.gov/research/fundingpages/funding.aspx. Accessed March 16, 2015.40

Abbreviation: NIH, National Institutes of Health.

over the past decade (Figure 1). There has also been a similar increase in the number of stem-cell-based clinical trials worldwide. Li et al ${ }^{20}$ examined more than 4,700 stem cell clinical trials in global registries (as of January 2013) and found an increase in the percentage of novel clinical trials from 2004 to 2011 . Approximately 25\% of these trials are for cardiovascular disease, and at least $16 \%$ are for neurological diseases/conditions, ${ }^{20}$ which would include four of the five top conditions for travel to clinics (Parkinson's disease, multiple sclerosis, stroke, and spinal cord injury ${ }^{18}$ ).

Industry involvement is critical for new technologies to advance to patients, and it appears that the economic incentive is present. The worldwide market for stem cells was estimated to be worth $\$ 26.2$ billion (US dollars) in 2013 and, growing at a $24.2 \%$ compound annual growth rate; it is expected to reach $\$ 119.5$ billion by $2019 .{ }^{11}$ Yet, the large majority of new clinical trials (87\%) was still in early-phase testing, ${ }^{20}$ and will require many years before determining safety and efficacy and ultimately reaching patients. Li et al ${ }^{20}$ found that industry was involved as the principal sponsor or a collaborator in $25 \%$ of the novel clinical trials; however, this may be greatly underestimated as it only includes what is reported in the registries. Indeed, both small biotechnology companies and larger pharmaceutical companies are engaged in clinical trials. In terms of novel clinical trials, industry was most heavily engaged in gastrointestinal diseases (48\%), lung disease (40\%), cartilage disease (36\%), neurological diseases (28\%), diabetes (26\%), and bone conditions ( $25 \%$ ) - diseases which may be treated with alternative stem cell sources. While most of the approved stem cell therapies utilize blood or bone marrow stem cells to treat hematologic, cancer, and immune conditions, novel clinical trials may capture the growing stem cell market by utilizing stem cells from other tissues to address a broader range of diseases.

Meeting comprehensive government regulations is a critical part of getting stem cell therapies to the bedside, such that technology development must occur with the regulations in mind. Extensive regulations exist in the US, and several other countries. Later in this article, we describe the US and other government regulations associated with the use of human stem cell and tissues in regenerative medicine.

\section{Educating patients on cell therapy}

Internet and web-based resources are a significant source of health information for patients worldwide. ${ }^{21}$ The internet is used to learn about symptoms, diagnoses, tests, and treatments; tools exist to find out how others have rated doctors and hospitals, and increasingly to obtain user-based information on drug treatment or therapy. ${ }^{21}$

The internet proliferation of stem cell clinics offering unproven therapies for patients has driven key scientific stem cell organizations to advocate for patient protection in various forms. For example, the International Society for Stem Cell Research (ISSCR) released The Guidelines for the Clinical Translation of Stem Cells which called for rigorous standards in the development of stem cell therapies and outlining what needs to be accomplished to move stem cells from promising research to proven treatments. ${ }^{22}$ The goal of ISSCR is to provide a warning on the dangers of stem cell tourism and to ensure that the promise of stem cell research is delivered to patients in a safe, effective, and fair manner. Similarly, the International Society for Cell Therapy (ISCT) advocated patient protection through a number of actionable steps including scientific development of the field and enabling ethical and compassionate early access to promising cellular therapies. ${ }^{9}$ However, these are scientific organizations, whose audience is most often scientists, and these sites may not be accessed as frequently by patients.

We examined the websites of disease or condition-specific professional health organizations. We found that $71 \%$ of disease or condition-specific professional organizations provided some information regarding current status of stem cell research for the specific condition. However, the level of this information was variable, ranging from easy access on the homepage to less visible access that required searching the website using keywords (Supplementary material). In addition, of the $71 \%$ with information, only $18 \%$ provided a specific warning or cautions regarding use of stem cell therapy abroad (Figure 2). In addition, the US NIH website does not provide a direct warning, rather it directs viewers 


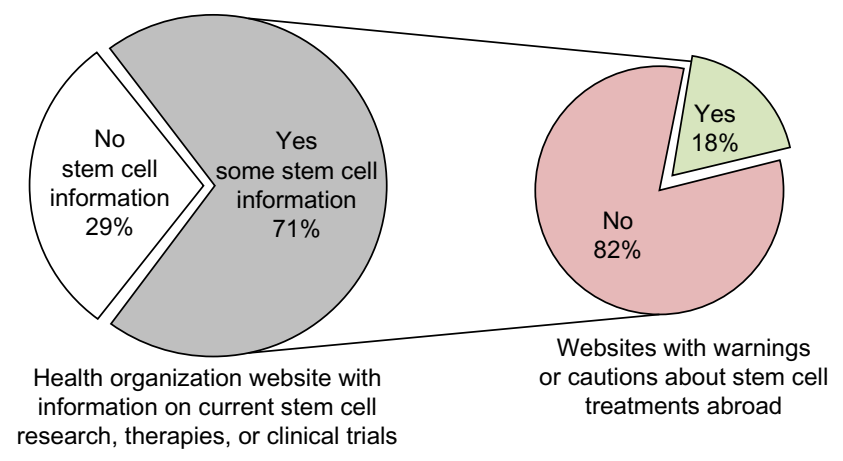

Figure 2 Few health organization websites provide warnings to patients regarding unproven or under-regulated stem cell treatments.

Notes: Health organization websites can be frequented by patients seeking a range of information. We found that while $71 \%$ of these websites (eg, www.cerebralpalsy. org, www.nationalmssociety.org, and www.cff.org) provided some information about stem cell therapies, only $18 \%$ of those provided a warning or caution regarding treatments abroad at unproven clinics.

to the ISSCR website to "help you evaluate claims you may have seen regarding stem cell treatments".

Few online tools exist for patients to cross-check the claims made on the stem cell clinic websites. The ISCT proposed, in line with ideas proposed by the ISSCR, to create a "Cell Therapy Guide for Patients and Caregivers", as an accessible online tool which would include regular updates. ${ }^{9}$ The guide could explain data supporting cell therapies. In addition, it would define approved/standard therapies, controlled clinical trials, and treatments not subject to independent scientific review, as well as valid compassionate use of unapproved therapies.

Many organizations recognize that patients who are considering to travel need information to provide guidance in their decision-making. To this end, several professional societies have website resources about stem cell therapies, particularly in regards to unproven treatments (Table 1). The US, eg, does provide a list of US-approved therapies (Table 1 for link); however, no scientific website or government agency can provide a list of globally approved stem cell therapies. Therefore, determining which stem cell therapies have received government approval and/or are shown to be scientifically credible and medically effective can be a difficult task for patients.

The ISSCR's website "A Closer Look at Stem Cells" appears to provide the most comprehensive guide for patients to use in conjunction to involving their own physician (Table 2). Several other global networks such as Canadian Stem Cell Network (http://www.stemcellnetwork.ca), EuroStemCell (http://www.eurostemcell.org), and Stem Cells Australia (http://www.stemcellsaustralia.edu.au) provide useful information and will refer back to the ISSCR's A Closer Look at Stem Cells website for the patient handbook which was written in 2010, but still the standard guide as of 2015.
Recently, $\mathrm{Scott}^{23}$ and Trounson et al ${ }^{24}$ discuss the need for highly trained stem cell experts to help educate patients regarding new stem cell therapies that may be unapproved or in clinical trials. $\operatorname{Scott}^{23}$ suggested the notion of a stem cell counselor, similar to a genetics counselor who could help to educate patients by explaining risks, and benefits, and therapeutic alternatives and could provide information about unproven transplants offered by overseas clinics. Regarding transnational travel, a properly trained stem counselor as suggested by $\mathrm{Scott}^{23}$ and Trounson et $\mathrm{al}^{24}$ can be a tremendous resource to educate patients and families so they are fully aware of the dangers of unproven benefits of transplants offered often without rigorous government approval. Stem cell therapy counselor can help patients objectively evaluate the risks associated certain procedures and how efficacious they are based on published medical literature. Scott ${ }^{23}$ detailed how stem cell counselors can be trained and certified in stem cell sciences and related ethical, legal, and social implications. $\operatorname{Scott}^{23}$ suggested a curriculum that would provide counselors with the tools to address major issues facing the clinical stem cell field and offered a candidate recruitment and clinical site interface scheme. It is noteworthy that genetic counseling programs are a good model for stem cell counseling. Genetic counseling programs are available in most campuses and training can be offered for students and health workers interested in becoming counselors.

Similar to $\mathrm{Scott}^{23}$ and Trounson et al, ${ }^{24}$ ISCT suggested that their organization could partner with and provide resources to patient advocacy groups to provide a personalized and empathetic connection with patients interested in novel cellbased therapies. They would provide patients with access to experts and professional recommendations. As the number of new clinical trials is likely to continue to increase, ${ }^{24}$ stem cell counselors would fill a growing void to help patients who are in need of new health-care options (Table 2).

\section{Government regulation of cell- based products}

To highlight the stringency with which new medical treatments are advanced, we present an overview of the US system in addressing new cell-based products. In the US, cell products must follow regulatory guidelines of the US Food and Drug Administration (FDA). The European Union (EU), Australia, Canada, and other countries have similar regulations for the use of postnatal human cells, tissues, and cellular and tissue-based products (HCT/Ps). Table 1 provides a list of cell therapy products that have received US FDA or EU European Medicines Agency (EMEA) approval and some products with other government approval. Despite extensive 
Table I Approved cell therapy products by the US FDA, EU EMEA, and non-third-world countries

\begin{tabular}{|c|c|c|c|c|}
\hline \multirow[t]{2}{*}{ Approval } & \multicolumn{2}{|l|}{ Product } & \multirow[t]{2}{*}{ Condition } & \multirow[t]{2}{*}{ Cell type } \\
\hline & Company & $\begin{array}{l}\text { Company } \\
\text { headquarters }\end{array}$ & & \\
\hline $\begin{array}{l}1997 \\
\text { US FDA approval }\end{array}$ & $\begin{array}{l}\text { Carticel } \\
\text { Genzyme BioSurgery }\end{array}$ & $\begin{array}{l}\text { Cambridge, } \\
\text { MA, USA }\end{array}$ & Articular cartilage damage in the knee & $\begin{array}{l}\text { Autologous chondrocytes } \\
\text { (adult/differentiated) }\end{array}$ \\
\hline $\begin{array}{l}1998 \\
\text { US FDA approval }\end{array}$ & $\begin{array}{l}\text { Apligraf } \\
\text { Organogenesis }\end{array}$ & $\begin{array}{l}\text { Canton, } \\
\text { MA, USA }\end{array}$ & $\begin{array}{l}\text { Diabetic foot ulcers and venous leg } \\
\text { ulcers }\end{array}$ & $\begin{array}{l}\text { Neonatal foreskin allogeneic } \\
\text { keratinocytes and fibroblasts in } \\
\text { bovine collagen scaffold }\end{array}$ \\
\hline $\begin{array}{l}2009 \\
\text { EU EMEA approval }\end{array}$ & $\begin{array}{l}\text { ChondroCelect }{ }^{\circledR} \\
\text { TiGenix }\end{array}$ & $\begin{array}{l}\text { Leuven, } \\
\text { Belgium }\end{array}$ & $\begin{array}{l}\text { Single symptomatic cartilage defects in } \\
\text { the knee }\end{array}$ & $\begin{array}{l}\text { Autologous chondrocytes } \\
\text { (adult/differentiated) }\end{array}$ \\
\hline $\begin{array}{l}2010 \\
\text { US FDA approval }\end{array}$ & $\begin{array}{l}\text { Provenge } \\
\text { Dendreon }\end{array}$ & $\begin{array}{l}\text { Seattle, } \\
\text { WA, USA }\end{array}$ & $\begin{array}{l}\text { Asymptomatic or hormone refractory } \\
\text { prostate cancer }\end{array}$ & $\begin{array}{l}\text { Autologous dendritic cells } \\
\text { (adult/differentiated) }\end{array}$ \\
\hline $\begin{array}{l}2010 \\
\text { US FDA approval }\end{array}$ & $\begin{array}{l}\text { Gintuit } \\
\text { Organogenesis }\end{array}$ & $\begin{array}{l}\text { Canton, } \\
\text { MA, USA }\end{array}$ & $\begin{array}{l}\text { Asymptomatic or hormone refractory } \\
\text { prostate cancer }\end{array}$ & $\begin{array}{l}\text { Autologous dendritic cells } \\
\text { (adult/differentiated) }\end{array}$ \\
\hline $\begin{array}{l}2011 \\
\text { Korean approval }\end{array}$ & $\begin{array}{l}\text { Hearticellgram-AMI } \\
\text { FCB-Pharmicell }\end{array}$ & $\begin{array}{l}\text { Seongnam, } \\
\text { South Korea }\end{array}$ & Heart repair postmyocardial infarction & $\begin{array}{l}\text { Autologous bone marrow-derived } \\
\text { mesenchymal stem cells }\end{array}$ \\
\hline $\begin{array}{l}2011 \\
\text { US FDA approval }\end{array}$ & $\begin{array}{l}\text { Laviv (Azficel-T) } \\
\text { Fibrocell Technologies }\end{array}$ & $\begin{array}{l}\text { Exton, } \\
\text { PA, USA }\end{array}$ & $\begin{array}{l}\text { Moderate-to-severe nasolabial fold } \\
\text { wrinkles in adults }\end{array}$ & Autologous fibroblasts \\
\hline $\begin{array}{l}2012 \\
\text { US FDA approval }\end{array}$ & $\begin{array}{l}\text { Gintuit } \\
\text { Organogenesis Incorporated }\end{array}$ & $\begin{array}{l}\text { Canton, } \\
\text { MA, USA }\end{array}$ & $\begin{array}{l}\text { Topical application to a surgically created } \\
\text { vascular wound bed in the treatment of } \\
\text { mucogingival conditions in adults }\end{array}$ & $\begin{array}{l}\text { Allogeneic cultured keratinocytes } \\
\text { and fibroblasts in bovine collagen }\end{array}$ \\
\hline $\begin{array}{l}2012 \\
\text { US FDA approval }\end{array}$ & $\begin{array}{l}\text { Laviv } \\
\text { Fibrocell Science Inc. }\end{array}$ & $\begin{array}{l}\text { Exton, } \\
\text { PA, USA }\end{array}$ & $\begin{array}{l}\text { Moderate-to-severe nasolabial fold } \\
\text { wrinkles }\end{array}$ & $\begin{array}{l}\text { Autologous fibroblasts } \\
\text { (adult/differentiated) }\end{array}$ \\
\hline $\begin{array}{l}2012 \\
\text { Health Canada } \\
\text { New Zealand }\end{array}$ & $\begin{array}{l}\text { Prochymal } \\
\text { Osiris }\end{array}$ & $\begin{array}{l}\text { Columbia, } \\
\text { MA, USA }\end{array}$ & $\begin{array}{l}\text { Graft vs host disease in children who } \\
\text { are refractory to steroid therapy } \\
\text { post-BMT }\end{array}$ & $\begin{array}{l}\text { Allogeneic mesenchymal stem cells } \\
\text { from donor bone marrow }\end{array}$ \\
\hline $\begin{array}{l}2012 \\
\text { Korean approval }\end{array}$ & $\begin{array}{l}\text { Cartistem } \\
\text { Medipost }\end{array}$ & $\begin{array}{l}\text { Gyeonggi-do, } \\
\text { South Korea }\end{array}$ & $\begin{array}{l}\text { Traumatic and degenerative } \\
\text { osteoarthritis }\end{array}$ & $\begin{array}{l}\text { Allogeneic mesenchymal stem cells } \\
\text { from donor umbilical cord blood }\end{array}$ \\
\hline $\begin{array}{l}2012 \\
\text { Korean approval }\end{array}$ & $\begin{array}{l}\text { Cupistem } \\
\text { Anterogen }\end{array}$ & $\begin{array}{l}\text { Seoul, } \\
\text { South Korea }\end{array}$ & Anal fistula in Crohn's disease & Autologous fat-derived "stem cells" \\
\hline $\begin{array}{l}2011 \\
\text { US FDA approval }\end{array}$ & $\begin{array}{l}\text { Hemacord } \\
\text { New York Blood Center }\end{array}$ & $\begin{array}{l}\text { New York, } \\
\text { NY, USA }\end{array}$ & $\begin{array}{l}\text { Disorders affecting the hematopoietic } \\
\text { system that are inherited, acquired, or } \\
\text { result from myeloablative treatment }\end{array}$ & $\begin{array}{l}\text { Allogeneic hematopoietic } \\
\text { progenitor cell from cord blood }\end{array}$ \\
\hline $\begin{array}{l}2012 \\
\text { US FDA approval }\end{array}$ & $\begin{array}{l}\text { HPC, Cord Blood } \\
\text { Clinimmune Labs, University of } \\
\text { Colorado Cord Blood Bank }\end{array}$ & $\begin{array}{l}\text { Aurora, } \\
\text { CO, USA }\end{array}$ & $\begin{array}{l}\text { Disorders affecting the hematopoietic } \\
\text { system that are inherited, acquired, or } \\
\text { result from myeloablative treatment }\end{array}$ & $\begin{array}{l}\text { Allogeneic hematopoietic } \\
\text { progenitor cell from cord blood }\end{array}$ \\
\hline $\begin{array}{l}2012 \\
\text { US FDA approval }\end{array}$ & $\begin{array}{l}\text { Hematopoietic Progenitor Cell } \\
\text { Ducord, HPC Cord Blood, Duke } \\
\text { University School of Medicine }\end{array}$ & $\begin{array}{l}\text { Durham, } \\
\text { NC, USA }\end{array}$ & $\begin{array}{l}\text { Disorders affecting the hematopoietic } \\
\text { system that are inherited, acquired, or } \\
\text { result from myeloablative treatment }\end{array}$ & $\begin{array}{l}\text { Allogeneic hematopoietic } \\
\text { progenitor cell from cord blood }\end{array}$ \\
\hline $\begin{array}{l}2013 \\
\text { US FDA approval }\end{array}$ & $\begin{array}{l}\text { HPC, Cord Blood BLA I } 25432 \\
\text { LifeSouth Community Blood } \\
\text { Centers, Inc. }\end{array}$ & $\begin{array}{l}\text { Gainesville, } \\
\text { FL, USA }\end{array}$ & $\begin{array}{l}\text { Disorders affecting the hematopoietic } \\
\text { system that are inherited, acquired, or } \\
\text { result from myeloablative treatment }\end{array}$ & $\begin{array}{l}\text { Allogeneic hematopoietic } \\
\text { progenitor cell from cord blood }\end{array}$ \\
\hline $\begin{array}{l}2013 \\
\text { US FDA approval }\end{array}$ & $\begin{array}{l}\text { ALLOCORD } \\
\text { SSM Cardinal Glennon } \\
\text { Children's Medical Center }\end{array}$ & $\begin{array}{l}\text { St Louis, } \\
\text { MO, USA }\end{array}$ & $\begin{array}{l}\text { Disorders affecting the hematopoietic } \\
\text { system that are inherited, acquired, or } \\
\text { result from myeloablative treatment }\end{array}$ & $\begin{array}{l}\text { Allogeneic hematopoietic } \\
\text { progenitor cell from cord blood }\end{array}$ \\
\hline $\begin{array}{l}20 I 5 \\
\text { EU EMEA approval }\end{array}$ & $\begin{array}{l}\text { Holoclar } \\
\text { Chiesi Farmaceutici S.p.A. }\end{array}$ & Parma, Italy & Corneal diseases & $\begin{array}{l}\text { Ex vivo expanded autologous } \\
\text { human corneal epithelial cells } \\
\text { containing stem cells }\end{array}$ \\
\hline
\end{tabular}

Notes: Several cell products have received US FDA approval| ${ }^{41}$ and are in current use for a number of patients. Cell products that were approved early on were based on autologous cells, in recent years several allogeneic stem cell products received approval. As of 2015, the EU EMEA has only approved autologous cell products, while the US and other countries have approved some allogeneic products in recent years. Other governing bodies such as India's National Apex Committee for Stem Cell Research and Therapy (http://www. icmr.nic.in/icmrnews/NAC.htm) have no approved therapies other than standard hematopoietic stem cell transplantation for hematopoietic disorders. Stem cell therapies offered in People's Republic of China must be registered with the State Food and Drug Administration of China (SFDA; Beijing, People's Republic of China), however, there are no approved quality control guidelines available yet. The Ministry of Health, Labor and Welfare (Tokyo, Japan) requires a "confirming application" (referring to basic quality of the medicine and results of animal experiments) in addition to the standard application for clinical trials. Regulations in many counties are unclear, incomplete, or in the process of being developed. Data from the US FDA. Marketed products.Available from: http://www.Fda.Gov/biologicsbloodvaccines/cellulargenetherapyproducts/approvedproducts/default.Htm.Accessed October I5, 20I5. ${ }^{41}$ Abbreviations: US FDA, US Food and Drug Administration; EU EMEA, EU European Medicines Agency; BMT, blood and marrow transplantation. 
Table 2 Resources for patients

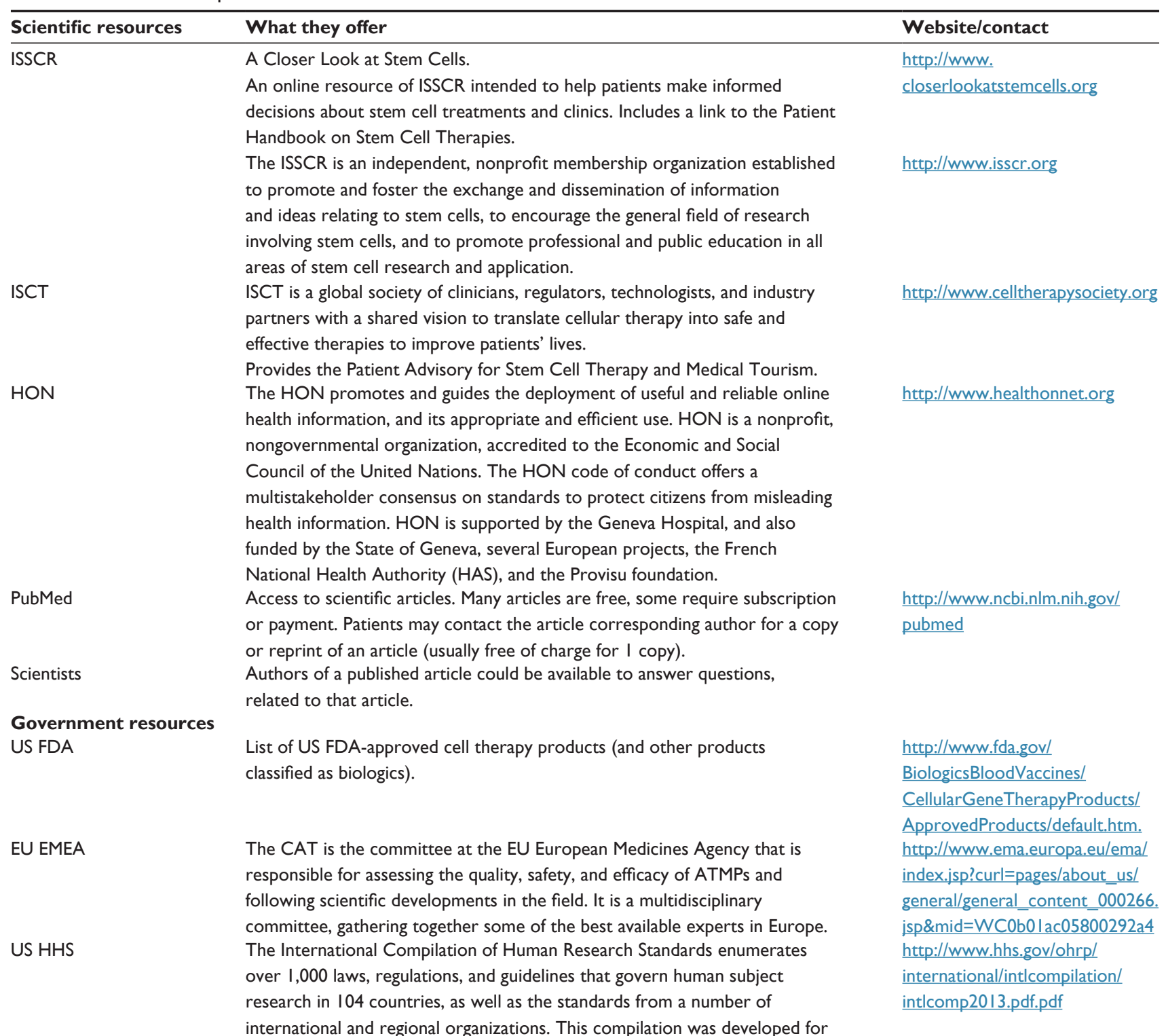

use by researchers, IRBs/research ethics committees, sponsors, and others who are involved in human subject research around the world.

The process of determining what is legal and approved in many countries difficult. This compilation may provide links to regulatory offices, or help guide patients to the responsible office. Patients also should keep in mind that many countries are in the process of creating or updating regulations related to cell therapy products.

US HHS ClinicalTrials.gov is a registry and results database of publicly and privately supported clinical studies of human participants conducted around the world.

https://www.clinicaltrials.gov

Abbreviations: ISSCR, International Society for Stem Cell Research; ISCT, International Cell Therapy Society; HON, Health on the Net Foundation; US FDA, US Food and Drug Administration; EU EMEA, EU European Medicines Agency; US HHS, US Health and Human Services; CAT, Committee for Advanced Therapies; ATMPs, advancedtherapy medicinal products; IRBs, institutional review boards.

stem cell research over the past two decades, most stem cell products have only recently been approved, and many are in the process of receiving regulatory approvals..$^{25}$

The US FDA's regulation of $\mathrm{HCT} / \mathrm{Ps}$ is intended to protect the public from risks associated with cell therapies.
The agency's guidelines focus on 1) limiting the risk of transmission of communicable disease from donors to recipients; 2) establishing manufacturing practices that minimize the risk of contamination; 3) demonstrating the safety and effectiveness for cells and tissues. ${ }^{26,27} \mathrm{HCT} / \mathrm{Ps}$ 
are regulated predominantly in 21 C.F.R. Part 1271. While other HCT/Ps are regulated under both Part 1271 and US FDA's Federal Food, Drug, and Cosmetic Act (premarket and postmarket regulation of medical devices and drugs), and section 351 of the Public Health Service (PHS) Act for biological products.

In 1993, the US FDA began establishing regulatory and guidance documentation to provide a biologics regulatory framework for the use of HCT/Ps. ${ }^{28}$ Subsequently, other key regulatory and guidance documents have been released. At the least, these documents outline that cell products must be manufactured following Good Manufacturing Practices and Good Tissue Practices. Additional levels of regulation exist if the cell product is "more-than-minimally manipulated".

For cells, minimal manipulation means processing that does not alter the relevant biological characteristics of cells or tissues. Examples of products regulated as $361 \mathrm{HCT} / \mathrm{Ps}$ include bone marrow or blood transplants and organ transplants. HCT/Ps that meet Part 1271 criteria for regulation solely under section 361 of the PHS Act and the regulations in Part 1271 are called "361 HCT/Ps", and are not subject to any premarket review requirements. More-than-minimal manipulation includes processes such as density-gradient separation, cell selection, centrifugation, cryopreservation, cell activation, encapsulation, ex vivo expansion, and gene modifications. Cells that undergo ex vivo manipulation may lose potency, acquire infectious contaminants, or become transformed/tumorigenic due to the cell culture conditions. ${ }^{29-33}$ Most advanced cellular therapies meet criteria for the more-than minimally manipulated category. ${ }^{34}$

\section{Safety and efficacy risks exist at all steps in the manufacturing process}

US FDA license, approval, or clearance is required for clinical use of HCT/Ps that do not meet the criteria established in Section 1271.10. All steps of HCT/Ps manufacturing require compliance with Current Good Tissue Practice. A clinical environment or company involved in any of the manufacturing steps - procurement, processing, storage, and distribution - could potentially introduce a risk to safety or efficacy of the cell product. In procurement, donor eligibility is determined based on testing for relevant communicable disease agents and diseases, and is required for all donors of cells or tissue used in HCT/Ps. In processing, Good Manufacturing Practices regulations apply to all phases of cell/tissue collection, processing and expansion, and storage. A compliant quality control program for record and process control is required as is a material control program with detailed descriptions of the manufacturing process and documentation of source country for all materials of animal origin. Storage steps may involve HCT/P product cryopreservation; subsequently, compliance requires that the process includes an understanding of the shelf-life and how the freezing and storage process affects the HCT/Ps. Finally, distribution, standards for in-process, and final product quality must be established.

The US FDA application for licensure requires that companies demonstrate that the $\mathrm{HCT} / \mathrm{P}$ product standards and procedures are based on good science and thorough and extensive data. A comprehensive product characterization program is needed to understand the products and how they may be clinically beneficial. US FDA product review and licensing is a long and difficult process that ensures public safety and trust. At the same time, new product applications may benefit by approvals of other cell-based products. As clinical settings and companies establish environments which meet regulatory licensing standards, scientifically-sound technologies may be expedited to reach patients sooner.

The EU EMEA is the EU regulating body with authorization and supervision of cell therapy products and other "advanced therapy medicinal products". ${ }^{35}$ In 2011, the EU EMEA's Committee for Advanced Therapies released the Guideline on Human Cell-based Medicinal Products (EMEA/CHMP/410869/2006) for the Marketing Authorization Application. Like the US FDA guidelines, the document details the quality and manufacturing, nonclinical, and clinical aspects required for Marketing Authorization Application approval. Emphasis is placed on starting and raw materials, manufacturing process, quality control, validation of the manufacturing process, development pharmaceutics, traceability and biovigilance, and comparability.

In 2012, Health Canada was the first approving body in the world to approve a manufactured allogeneic stem-cellbased drug. Osiris Therapeutics of Maryland, USA developed Prochymal ${ }^{\mathbb{}}$ (remestemcel-L, adult human mesenchymal stem cells for intravenous infusion), a liquid cell suspension of ex vivo cultured adult mesenchymal stem cells derived from the bone marrow of healthy adult donors and intended to treat a systemic disease - acute graft versus host disease. ${ }^{36}$ Prochymal is the first stem cell therapy approved for clinical use in patients, specifically pediatric patients. Health Canada regulations are outlined in the Safety of Human Cells, Tissues and Organs for Transplantation Regulations (CTO Regulations ${ }^{37}$ ). The CTO Regulations detail requirements to ensure 
safety in processing; storage; record keeping; distribution; importation; and error, accident, and adverse reaction investigation and reporting. ${ }^{37}$ Following Health Canada's approval, Osiris was required to continue a Risk Management Plan which included postmarket studies related to benefits of Prochymal to outweigh risk of its use. ${ }^{38}$

In Australia, HCT/Ps biologicals are regulated by the Therapeutic Goods Administration. ${ }^{39}$ Like other governments, the Therapeutic Goods Administration's regulatory framework requires substantial evidence that the particular therapy or product is safe and effective, and it imposes different levels of regulation on the biological depending on risk, extent of manipulation, and whether the intended use is its usual biological function. ${ }^{39}$

\section{Conclusion}

The increase in transnational health care is associated with a number of issues including legal, social, and economic concerns. A subset of this health-care market is cell therapeutics with a particular safety concern related to unproven and unregulated therapies. Because many patients who seek these therapies are facing life-threatening conditions and are willing to take on increased risk in search of hope, and because unscrupulous clinics market to this hope, the scientific and medical communities are urging a message of caution.

While patients wait for new cell therapies to pass through the regulatory process, there is a need for clear information on what may or may not be safe. There are a number of areas around the world that have little regulations and unregulated treatments continue to pose a health risk to patients and a risk to careful development of the field. For example, simply determining if a particular treatment in some Asian counties is approved by the government is a difficult task. Patients are encouraged to engage their physician and reach out to scientific resources. It is yet to be determined if the notion of stem cell counselors will gain traction. Certainly, the rise in stem cell clinical trials and more treatment options will provide another push for additional resources for patients making critical decisions. Despite these challenges, the cell therapeutics field is making progress as evidenced by the increasing number of approved products.

\section{Disclosure}

The authors report no conflicts of interest in this work.

\section{References}

1. Lunt N, Exworthy M, Hanefeld J, Smith RD. International patients within the NHS: a case of public sector entrepreneurialism. Soc Sci Med. 2015;124:338-345.
2. Bell D, Holliday R, Ormond M, Mainil T. Transnational healthcare, cross-border perspectives. Soc Sci Med. 2015;124:284-289.

3. Mainil T, Van Loon F, Dinnie K, Botterill D, Platenkamp V, Meulemans H. Transnational health care: from a global terminology towards transnational health region development. Health Policy. 2012;108(1):37-44.

4. Bustamante AV. Globalization and medical tourism: the North American experience comment on "patient mobility in the global marketplace: a multidisciplinary perspective". Int J Health Policy Manag. 2014; 3(1):47-49.

5. Hanefeld J, Lunt N, Smith R, Horsfall D. Why do medical tourists travel to where they do? The role of networks in determining medical travel. Soc Sci Med. 2015;124:356-363.

6. Luntand N, Mannion R. Patient mobility in the global marketplace: a multidisciplinary perspective. Int $J$ Health Policy Manag. 2014; 2(4):155-157.

7. Hopkins L, Labonte R, Runnels V, Packer C. Medical tourism today: what is the state of existing knowledge? J Public Health Policy. 2010; 31(2):185-198.

8. Centers for Disease Control. The Pre-Travel Consultation. In Yellow Book. Atlanta, GA: Centers for Disease Control and Prevention; 2014.

9. Gunter KC, Caplan AL, Mason C, et al. Cell therapy medical tourism: time for action. Cytotherapy. 2010;12(8):965-968.

10. Patients beyond borders. Medical tourism statistics and facts. Available from: http://www.patientsbeyondborders.com/medicaltourism-statistics-facts. Accessed October 15, 2015.

11. Transparency market research. Stem Cells Market - Global Industry Analysis, Size, Share, Growth, Trends and Forecast, 2012-2018. Albany, NY: Transparency Market Research; 2013.

12. World Health Organization. Cardiovascular diseases. Factsheet no 317 [updated January 2015]. Geneva, Switzerland: World Health Organization.

13. Stewart B, Wild CP. World Cancer Report 2014. Geneva, Switzerland: World Health Organization.

14. US Department of Health and Human Services. Organ Procurement and Transplantation Network (OPTN) [homepage]. Available at: http:// optn.transplant.hrsa.gov/. Accessed November 9, 2015.

15. McBride MA, Harper AM, Taranto SE. The OPTN waiting list, 1988-2002. Clin Transpl. 2003:53-64.

16. Concord Corporate Finance Research. Biomaterialien und Tissue Engineering am Neuen Markt. Frankfurt, Germany: Concord Effekten AG; 2002.

17. Landesbank Baden-Württemberg Equity Research. Tissue Engineering. Stuttgart, Germany: Landesbank Baden-Württemberg Equity Research; 2001.

18. Connolly R, O'Brien T, Flaherty G. Stem cell tourism - a web-based analysis of clinical services available to international travellers. Travel Med Infect Dis. 2014;12(6 Pt B):695-701.

19. Lau D, Ogbogu U, Taylor B, Stafinski T, Menon D, Caulfield T. Stem cell clinics online: the direct-to-consumer portrayal of stem cell medicine. Cell Stem Cell. 2008;3(6):591-594.

20. Li MD, Atkins H, Bubela T. The global landscape of stem cell clinical trials. Regen Med. 2014;9(1):27-39.

21. Fox S, Maeve D. Mobile Health 2012. Pew Research Center.

22. International Society for Stem Cell Research. Guidelines for the Clinical Translation of Stem Cells. Skokie, IL:ISSCR; 2008.

23. Scott CT. The case for stem cell counselors. Stem Cell Reports. 2015;4(1):1-6.

24. Trounson A, DeWitt ND, Feigal EG. The alpha stem cell clinic: a model for evaluating and delivering stem cell-based therapies. Stem Cells Transl Med. 2012;1(1):9-14.

25. Berger AC, Beachy SH, Olsin H. Stem Cell Therapies: Opportunities for Ensuring the Quality and Safety of Clinical Offerings: Summary of a Joint Workshop. Washington, DC: National Academies Press; 2014.

26. Committee on Ranking FDA Product Categories Based on Health Consequences Phase II, National Research Council. A Risk-Characterization Framework for Decision-Making at the Food and Drug Administration. Washington, DC: National Academies Press; 2011. 
27. US Food and Drug Administration. Guidance for Industry: Current Good Tissue Practice (CGTP) and Additional Requirements for Manufacturers of Human Cells, Tissues, and Cellular and Tissue-Based Products (HCT/PS). Silver Spring, MD: FDA; 2011.

28. US Food and Drug Administration. Application of Current Statutory Authority to Human Somatic Cell-therapy and Gene-therapy Products [Fed Reg 58:53248-51]. Silver Spring, MD: FDA; 1993.

29. Kirouac DC, Zandstra PW. The systematic production of cells for cell therapies. Cell Stem Cell. 2008;3(4):369-381.

30. Parenteau NL. Commercial development of cell-based therapeutics: strategic considerations along the drug to tissue spectrum. Regen Med. 2009;4(4):601-611.

31. Carlson ME, Conboy IM. Loss of stem cell regenerative capacity within aged niches. Aging Cell. 2007;6(3):371-382.

32. Gazit R, Weissman IL, Rossi DJ. Hematopoietic stem cells and the aging hematopoietic system. Semin Hematol. 2008;45(4):218-224.

33. Deasy BM, Gharaibeh BM, Pollett JB, et al. Long-term self-renewal of postnatal muscle-derived stem cells. Mol Biol Cell. 2005; 16(7):3323-3333.

34. Burger SR. Current regulatory issues in cell and tissue therapy. Cytotherapy. 2003;5(4):289-298.
35. Schussler-Lenz M, Schneider CK. Clinical trials with advanced therapy medicinal products. Bundesgesundheitsblatt Gesundheitsforschung Gesundheitsschutz. 2010;53(1):68-74. German.

36. Pollack A. A stem-cell-based drug gets approval in Canada. The New York Times. May 17, 2012.

37. Health Canada. Guidance Document for Cell, Tissue and Organ Establishments. Safety of Human Cells, Tissues and Organs for Transplantation. Ottawa, ON: Health Canada; 2009.

38. Health Canada. Notice of Decision for Prochymal [Control Number 150026]. Available from: http://www.hc-sc.gc.ca/dhp-mps/prodpharma/ sbd-smd/drug-med/sbd_smd_2012_prochymal_150026-eng.php. Accessed October 15, 2015.

39. Wall DM, Prince HM. Regulation of cellular therapies: the Australian perspective. Cytotherapy. 2003;5(4):284-288.

40. National Institutes of Health, US Department of Health and Human Services. NIH Stem Cell Research Funding, fy 2002-2013. Bethesda, MD: NIH. Available from: http://stemcells.nih.gov/research/fundingpages/funding.aspx. Accessed March 16, 2015.

41. US FDA. Marketed products. Available from: http://www.Fda.Gov/ biologicsbloodvaccines/cellulargenetherapyproducts/approvedproducts/ default.Htm. Accessed October 15, 2015. 


\section{Supplementary material}

Websites of 102 health organizations were examined for content related to stem cell research and therapies for their associated disease conditions. Organizations were considered to have information regarding stem cells if language or direct, nonadvertisement links related to stem cell research and/or therapies were present on the homepage. Additionally, organizations were considered to have information regarding stem cells if a link to stem-cell-related information was found after searching the website using its search option.

\section{Publish your work in this journal}

Innovation and Entrepreneurship in Health is an international, peer reviewed, open access journal publishing original research, reports, reviews and commentaries on innovation and entrepreneurship in health. Special focus will be given to the theory, process, and practice of innovation and entrepreneurship by individuals and organizations within the health care context globally. The manuscript management system is completely online and includes a very quick and fair peer review system, which is all easy to use. Visit http://www.dovepress.com/ testimonials.php to read real quotes from published authors.

Submit your manuscript here: http://www.dovepress.com/innovation-and-entrepreneurship-in-health-journal 